IzABELA KowalsKa-PASZT

Uniwersytet Szczeciński

\title{
POSTKOLONIALNE ZAPISKI Z PODRÓŻY DO „KOLONII”. OSIP MANDELSZTAM PODRÓŻ DO ARMENII, JURIJ KARABCZIJEWSKIJ TĘSKNOTA ZA ARMENIĄ
}

Wybór tekstów, dokonany dla potrzeb przedstawianego artykułu, co oczywiste, nie jest przypadkowy ${ }^{1}$. Europejska literatura podróżnicza, odnotowuje we wstępie do swej monografii Mary Pratt, ukazując nowe kolonizowane obszary, kreowała „[...] pewien imperialny ład i porządek dla Europejczyków, którzy pozostawali 'u siebie””, i zapewniała „czytelnikom [...] poczucie posiadania odległych rejonów świata i prawa do nich”" . Analogicznie miała się rzecz z literaturą rosyjską i radziecką. Ewa Thompson, przyjmując

${ }^{1}$ Do ważkich radzieckich tekstów o Armenii, o „bolesnym miejscu”, jak ją określił Michaił Gasparow w jednym ze swych listów do Marii-Luise Bott („Читать меня подряд никому не интересно...”. Письма М.Л. Гаспарова к Марии-Луизе Ботт, 1981-2004 г2.; подготовка текста и публикация М.-Л. Ботт), „Новое литературное обозрение” 2006, nr 77, http://magazines. russ.ru/nlo/2006/77/ga19.html - 12.02.2016), należą także Lekcje Armenii Andrieja Bitowa (Уроки Армении, 1969) oraz Wszystkiego dobrego Wasilija Grossmana (Добро вам, 1962-1963).

${ }^{2}$ M.L. Pratt, Imperialne spojrzenie. Pisarstwo podróżnicze a transkulturacja, przeł. E.E. Nowakowska, Wydawnictwo Uniwersytetu Jagiellońskiego, Kraków 2011, s. 20. 
za poprawną i uzasadnioną badawczo tezę o realizowanych w praktyce rosyjskim i radzieckim imperiach ${ }^{3}, \mathrm{z}$ ich heterogennymi, polietnicznymi i multikulturowym społeczeństwami, o ich kolonialnie zorientowanym charakterze ${ }^{4}$, podjęła się odczytania tematu kolonialnego w pisarstwie rosyjskim XIX i XX stulecia. Badaczka wiąże narodziny rosyjskiego dyskursu imperialnego $\mathrm{z}$ literackimi przedstawieniami Kaukazu, które, „[...] miały swój udział w samopostrzeganiu Rosjan, jak też wpłynęły na postawy przyjmowane w stosunku do mieszkańców tego regionu" ${ }^{5}$, i nadały doświadczeniu imperialnemu status autorytetu tekstualnego ${ }^{6}$. Thompson zarzuca romantykom rosyjskim - Puszkinowi i Lermontowowi - protekcjonalne obrazowanie ${ }^{7}$ i trywializowanie Kaukazu ${ }^{8}$, fabrykowanie na użytek narodowej pamięci tekstualnej wizji Rosji jako surowej, ale dobroczynnej siły, nadającej porządek i tożsamość przedwiecznemu chaosowi ${ }^{9}$. W konkluzji stwierdza: „Już od pokoleń wpływy wielkiej poezji i zniekształceń wnoszonych przez ideologię kolonialną współdziałały w wytworzeniu obrazu Kaukazu jako chaotycznego, podzielonego, zbrodniczego i biednego, jako jednego $\mathrm{z}$ niezrozumiałych i niebezpiecznych regionów na obrzeżach Federacji 'Rosyjskiej”' 10 .

W odróżnieniu od omówionej tu perspektywy badawczej mnie interesują „miejsca słabe” w kulturze rosyjsko-radzieckiej, to znaczy te teksty literackie, które odnotowywały istnienie dyskursu imperialnego i podejmowały próbę jego dekonstrukcji, dlatego celem

\footnotetext{
${ }^{3}$ Р.Г. Суни, Уроки империи: Россия и Советский Союз, przeł. A. Smirnow, „Прогнозис" 2006, nr 8, http://www.intelros.ru/2007/08/09/uroki_imperii_ rossija_i_sovetskijj_sojuz.html (12.02.2016).

${ }^{4}$ Zob. E.M. Thompson, Trubadurzy imperium. Literatura rosyjska i kolonializm, przeł. A. Sierszulska, Universitas, Kraków 2000, s. 23-47.

${ }^{5}$ Tamże, s. 85.

${ }^{6}$ Tamże, s. 86.

7 Tamże, s. 95.

${ }^{8}$ Tamże, s. 113.

${ }^{9}$ Tamże, s. 100.

10 Tamże, s. 132.
} 
przedkładanych rozważań jest wskazanie i zinterpretowanie postkolonialnego wymiaru zaanonsowanych w tytule radzieckich zapisków z podróży. Nadmienię jedynie, że termin postkolonializm nie zakłada następstwa czasowego - „po kolonializmie”, a oznacza, jak ujęła to Ania Loomba, „kontestację kolonialnej dominacji i dziedzictwa kolonializmu"11.

Obie prozatorskie reminiscencje z wyjazdu dotyczą sowieckiej Armenii, utworzonej i przez okres siedemdziesięciu lat kontrolowanej, jak z perspektywy emigracji pisał ostatni premier Pierwszej Republiki Simon Wracjan, na mocy jednostronnej decyzji bolszewików:

Причины падения независимости Армении были не внутренними, а внешними. Республика Армения пала под объединенными ударами турок и большевиков. И в первую очередь, большевиков, потому что, если бы не поддержка Советской России, кемалистская Турция в тех условиях не осмелилась бы напасть на Армению ${ }^{12}$.

Czas, w jakim powstały i jaki sobą reprezentują (Mandelsztama - początek lat 30., Karabczijewskiego zaś - koniec lat 70. XX wieku), obejmuje prawie pięćdziesiąt lat, więc winien pozwolić dostrzec ewentualne kulturowo-społeczne zmiany w refleksjach podróżujących literatów. Ponadto autor Wskrzeszenia Majakowskiego w istotny dla utworu sposób odsyła do poetyckich obrazów akmeisty z jego cyklu „Armenia”. I wreszcie jeszcze jedna kwestia - żydowska składowa tożsamości, która łączy obu twórców i, moim zdaniem, w dużym stopniu mogła zadecydować o postkolonialnej narracji obu utworów.

Przodkowie Mandelsztama, pisze Michaił Epsztejn ${ }^{13}$, związani byli z północną częścią „krainy” żydowskiej (ojciec pochodził

11 A. Loomba, Kolonializm/Postkolonializm, przeł. N. Bloch, Wydawnictwo Poznańskie, Poznań 2011, s. 28.

12 С. Врацян, Армения между большевистским молотом и турецкой наковальнец, przeł. z wyd. ormiańskiego z roku 1941 w Bostonie, [b.w.], Erywań 1992. Cyt za: Московский договор 1921 года закрепил за Туриией завоеванные армянские территории, http://www.panarmenian.net/rus/ details/176913 (2.03.2016).

${ }_{13}$ М. Эпштейн, Слово и молчание. Метафизика русской литературь, Высшая школа, Москва 2006, s. 377-378. 
z Rygi, a matka z Wilna), w której niepodzielnie panowała rabiniczna scholastyka, a życie społeczne regulowały zasady Talmudu. I, dowodząc, że Mandelsztamowska poezja jest nie tyle filozoficzna, ile w swych podstawach talmudyczna właśnie, odwołuje się do cytatów z autobiograficznego Szumu сzasu (Шум времени, 19221924): „Как крошка мускуса наполнит весь дом, так малейшее влияние иудаизма переполняет целую жизнь. О, какой это сильный запах!"14. Judejski chaos i judejskie drżenie spowodowały chęć porzucenia przez poetę swego żydowstwa na rzecz idealizowanej pogańsko-chrześcijańskiej sztuki, stwierdza Władimir Gorensztejn, ale, wiedziony czy to zewem krwi, czy też logiką artystycznego doświadczania świata, z czasem uznał swe pochodzenie ${ }^{15}$.

Przystępując do odczytania Mandelsztamowskiej Podróży do Armепіi (Путешествие в Армению, 1933) należy mieć na uwadze jej literacką specyfikę. Sam autor w liście do Marietty Szaginian określił ją, chyba słusznie, jako „w połowie powieśc”, Wiktor Szkłowski natomiast, analizując ewolucję jego prozy, pisał: „Большой писатель Осип Эмильевич Манделыштам. Он написал сейчас книгу Путешествие в Армению. Он путешествует там среди грамматических форм, библиотек, книг, зданий, слов, вещей"16.

W tekście podzielonym przez autora śródtytułami na dość samodzielne fragmenty - te odnoszące się bezpośrednio do pobytu w Armenii, jej instytucji i mieszkańców to: Sewan, Aszot Awanesjan, Asztarak, Alagez, co liczebnie stanowi jedynie jego połowę, a kolejne cztery: Moskwa, Suchumi, Francuzi, Wokót naturalistów wydają się albo wcale nie związane $\mathrm{z}$ anonsowaną $\mathrm{w}$ tytule tematyką, albo, jak w przypadku Suchumi, jedynie częściowo. Jednakże uważna lektura podrozdziałów niewpisanych w ramy refleksji z podróży pozwala lepiej zrozumieć zamysł artystyczny ich autora. Otóż

14 О. Мандельштам, Шум времени, Im-Werden-Verlag, Москва-Augsburg 2002, s. 7, http://imwerden.de/pdf/mandelshtam_shum_vremeni.pdf (12.03.2016).

${ }^{15}$ В. Горенштейн, Перекресток Мандельштама, „Иерусалимский журнал” 2008, nr 28, http://magazines.russ.ru/ier/2008/28/go22.html (12.03.2016).

16 В. Шкловский, Гамбургский счет. Статьи, эссе, воспоминания (1914-1933), Советский писатель, Москва 1990, http://ib.co.ua/memoir/shklovskiyvictor/ gamburgskiyschet.jsp (20.03.2016). 
mieszkający w robotniczej moskiewskiej dzielnicy - Zamoskworieczje - narrator, wdzięczny swemu pochodzeniu za swą obcość w tym środowisku, notujący osobiste rozmyślania w rok po powrocie (przypomnę, że tekst datował Mandelsztam na lata 1931-1932), porusza kilka ważnych kwestii, zaczynając od, moim zdaniem, najważniejszej, która wyjaśnia sposób, w jaki kreślił obraz Armenii. Ukształtował go bowiem pod wpływem książki Paula Signaca D’Eugène Delacroix au néo impressionnisme ${ }^{17}$, która broniła osiągnięć przedstawicieli tego kierunku w malarstwie i odsyłała, między innymi, do marokańskich obrazów francuskiego romantyka Wesele żydowskie w Maroku i Kobiety algierskie. Radzieckiego poetę z Delacroix wydawała się łączyć w tym określonym momencie nie tylko fascynacja orientem i kolorem, ale także pozycja outsidera, atakowanego przez krytyków, i przekonanie o prawie do własnego, subiektywnego postrzegania rzeczy. Mandelsztam w podrozdziale Francuzi zdaje się nie tylko aprobować, ale i w pełni utożsamiać z taką optyką widzenia otaczającego świata, jaką ma podróżnik-oko, kontemplujący, a nie oglądający obrazy impresjonistów:

Для всех выздоравливающих от безвредной чумы наивного реализма я посоветовал бы такой способ смотреть картины. [...] Тончайшими кислотными реакциями глаз - орган, обладающий акустикой, наращивающий ценность образа, помножающий свои достижения на чувственные обиды, с которыми он нянчится, как с писаной торбой, поднимает картину до себя, ибо живопись в гораздо большей степени явление внутренней секреции, нежели апперцепции, то есть внешнего восприятия ${ }^{18}$.

Bój z „naturalistami”, który wiedzie dojrzały poeta, dotyczy sposobu i możliwości twórczego poznania. Choć docenia znaczenie ich koncepcji, to jako wzorzec, zdolny poruszyć i głębię, i wrażliwość, i osiągnąć przy tym pełnię, został przezeń wskazany Dante.

17 „По-видимому, кн.: Синьяк П. От Эж. Делакруа к неоимпрессионизму. М., 1913”. О. Мандельштам, Сочинения в двух томах, t. 2, Художественная литература, Москва 1990, s. 427.

${ }^{18}$ О. Мандельштам, Сочинения в четырех томах, t. 3, Арт-бизнес-центр, Москва 1994, s. 199-200. 
Sztuka, powiada Mandelsztam, wygrywa z „naukowym obiektywizmem”, ale wiele może stracić, gdy ktoś usiłuje ją normatywizować czy ograniczać. Z powyższego wynika, że Mandelsztamowskie zapiski z podróży do Armenii mają charakter kontemplacyjny, są wyrazem namysłu autora nad istotą sztuki, nad jej związkami z urodą i mądrością przyrody. To tekst głęboko filozoficzny, metaforyczny, w swej warstwie intymnej przesycony bólem, trwogą i nadzieją na twórcze odrodzenie.

Podróż Mandelsztama do Armenii zaczęła się w kwietniu 1930 roku (z dwoma przystankami, w obie strony, w Suchumi i Tbilisi) i trwała siedem miesięcy ${ }^{19}$. Przyczyn wyjazdu było zapewne kilka. W literaturze przedmiotu mowa jest o utrwalonych przez żonę Nadieżdę zarówno marzeniach, jak i poważnych zamiarach poety odwiedzenia dalekiej sowieckiej republiki, o instynktownej ucieczce, o ziszczonym pragnieniu ukrycia się z dala od literackiego skandalu, wywołanego zamieszaniem wokół przekładu/redakcji powieści o Dylu Sowizdrzale, który zamienił się w permanentną nagonkę o podtekście politycznym $^{20}$. Mowa jest także o poszukiwaniu przez poetę źródeł kultury europejskiej, a także o żydowskich paralelach, jakie wyzwoliła w nim „вожделенная” Armenia. Kiedy pierwsze starania o wyjazd w roku 1929 legły w gruzach, rozżalony Mandelsztam pisał:

Я китаец - никто меня не понимает. Халды-балды! Поедем в АлмаАту, где ходят люди с изюмными глазами, где ходит перс с глазами как яичница, где ходит сарт с бараньими глазами.

Халды-балды! Поедем в Азербайджан! ${ }^{21}$

Żartobliwie brzmiąca i dwukrotnie powtórzona fraza „Халдыбалды!” w połączeniu ze stwierdzeniem „Я китаец” słusznie kono-

${ }^{19}$ П. Нерлер, „Путешествие в Армению” и путешествие в Армению Осипа Мандельштама: попьтка реконструкиии, „Знамя” 2015, nr 11, http:// magazines.russ.ru/znamia/2015/11/23n.html (12.03.2016).

${ }^{20}$ Г. Кубатьян, Бегство в Армению и другие этюды о Мандельштаме, „Вопросы литературы” 2005, nr 5, http://voplit.ru/eText/2005/2005-5/2005-5/2005-5. html\#179 (14.04.2016).

${ }^{21}$ О. Мандельштам, Четвертая проза, w: В.В. Иргунов (red.), Антология самиздата, t. 1, Международный институт гуманитарно-политических исследований, Москва 2005, s. 202. 
tuje się z pustosłowiem. Jednak bajkowo-zabawowa powierzchnia tekstu aktywizuje sięgającą w wyjątkowo daleką przeszłość wiedzę historyczną i uświadamia znakomite zorientowanie autora w etniczno-cywilizacyjnej konfiguracji Kaukazu ${ }^{22}$. Otóż, jeśli nie mogę pojechać do Armenii, powiada Mandelsztam, to udam się od Ałma Aty, gdzie zobaczę jej mieszkańców, w tym Persa i Sarta, lub, co mi tam, pojadę do Azerbejdżanu. Ale ani tam, ani do Kazachstanu jechać nie chciał i, wspominając o Persie z oczami niczym jajecznica oraz Sartrze o baranich oczach, odsyła czytelnika do głębokiej historii niewielkiej sowieckiej republiki Armenii. Jej lud w VI wieku p.n.e. został podbity przez Starożytną Persję, która kolonizowała go, tworząc swoją satrapię. Protoplaści owych ówczesnych Persów - Ariowie - około 1300 roku p.n.e. przywędrowali na ziemie irańskie właśnie ze Środkowej Azji, a część z nich pozostała na miejscu dwudziestowiecznego Azerbejdżanu. Ekonim „Sartowie” odnosi się do osiadłych ludów Kazachstanu, które zachowały swój pradawny język perski ${ }^{23}$. W czasach panowania perskiego, czego poeta był świadom, chrześcijańscy Ormianie zostali zmuszeni do podporządkowania się muzułmańskiej dominacji. Po tym gdy stali się poddanymi imperium rosyjskiego (proces włączania Armenii do Rosji wówczas dość nieudolnie zapoczątkował Piotr I), mogli w porównaniu z muzułmańskimi mieszkańcami być postrzegani jako grupa w jakimś sensie uprzywilejowana. Konflikty etniczno-religijne na zawłaszczonym już przez Rosję Kaukazie przejawiały się w krwawych starciach pomiędzy Ormianami a azerbejdżańskimi tatarami podczas rewolucyjnego wrzenia, jakie rozlało się po kraju w roku 1905, kiedy doszło do krwawych starć ${ }^{24}$. Kolejne zwią-

${ }^{22}$ Zob. А. Зубов, Политическое будущзее Кавказа: опьт ретроспективносравнительного анализа, „Знамя” 2000, nr 4, http://magazines.russ.ru/ znamia/2000/4/zubov.html (11.04.2016).

${ }^{23}$ Zob. J. Rohoziński, Bawełna, samowary i Sartowie. Muzułmańskie okrainy carskiej Rosji 1795-1916, Dialog, Warszawa 2014.

24 „Однако общее успокоение в Империи, наступившее в 1906-1907 годах, перевело и этот конфликт в холодную форму. И армяне и азербайджанцы стремились законными путями вытеснить своих противников из зоны совместного чересполосного проживания в Елизаветпольской и Эриваньской губерниях". А. Зубов, Политическое будущее Кавказа... 
zane były z chwiejną dwuwładzą w Rosji i podsycaniem ich przez stronę turecką, a skutkowały rzezią Ormian, mieszkańców Baku we wrześniu 1918 roku czy miasta Szusza w roku 192025. Zapowiadana $\mathrm{w}$ programach i realizowana $\mathrm{w}$ praktyce budowa nowego multietnicznego państwa, opartego na deklarowanym przez bolszewickie władze niezbywalnym prawie narodów do samostanowienia („korenizacja”), na gwarancji ich równości i wzajemnego poszanowania, trwała już od dziesięciu lat i w efekcie miała doprowadzić, jak pisze Yuri Slezkine, do całkowitej likwidacji najmniejszych zatargów narodowościowych, do zbliżenia nierzadko przecież zwaśnionych grup etnicznych i zlania się $\mathrm{w}$ jeden bezklasowy naród radziec$\mathrm{ki}^{26}$. A Mandelsztam wbrew oficjalnej sowieckiej propagandzie,

${ }^{25}$ Mandelsztam podczas pobytu w Armenii pojechał do Szuszy, o czym pisze jego żona Nadieżda w swoich wspomnieniach: „Поездка в Нагорный Карабах - это осень 1930 года, последний выезд из Эривани, конец нашего путешествия по Армении. На рассвете мы выехали на автобусе из Гянджи в Шушу. Город начинался с бесконечного кладбища, потом крохотная базарная площадь, куда спускаются улицы разоренного города. Нам уже случалось видеть деревни, брошенные жителями, состоящие из нескольких полуразрушенных домов, но в этом городе, когда-то, очевидно, богатом и благоустроенном, картина катастрофы и резни была до ужаса наглядной. Мы прошлись по улицам, и всюду одно и то же: два ряда домов без крыш, без окон, без дверей. В вырезы окон видны пустые комнаты, изредка обрывки обоев, полуразрушенные печки, иногда остатки сломанной мебели. Дома из знаменитого розового туфа, двухэтажные. Все перегородки сломаны, и сквозь эти остовы всюду сквозит синее небо. Говорят, что после резни все колодцы были забиты трупами. Если кто и уцелел, то бежал из этого города смерти. На всех нагорных улицах мы не встретили ни одного человека. Лишь внизу - на базарной площади - копошилась кучка народу, но среди них ни одного армянина, только мусульмане. У О.М. создалось впечатление, будто мусульмане на рынке - это остатки тех убийц, которые с десяток лет назад разгромили город, только впрок им это не пошло: восточная нищета, чудовищные отрепья, гнойные болячки на лицах. Торговали горстями кукурузной муки, початками, лепешками... Мы не решились купить лепешек из этих рук, хотя есть нам хотелось... О.М. сказал, что в Шуше то же, что у нас, только здесь нагляднее и поэтому невозможно съесть ни куска хлеба... И воды не выпьешь из этих колодцев..." - Н. Мандельштам, Воспоминания. Книга третья, YMCA-PRESS, Париж 1978, http://www. belousenko.com/wr_mandelshtamn.htm (23.04.2016).

${ }^{26}$ Ю. Слезкин, СССР как коммунальная квартира, или каким образом социалистическое государство поочряло этническую обособленность, 
która nabierała coraz większą moc sprawczą, i instytucjonalnym działaniom stwierdza dobitnie w swych zapiskach: „Чужелюбие вообще не входит в число наших добродетелей. Народы СССР сожительствуют как школьники. Они знакомы лишь по классной парте да по большой перемене, пока крошится мел"27.

Mandelsztam nie tylko wie o skutkach tragicznej dominacji imperium osmańskiego czy to pod rządami sułtana, czy młodoturków, czy republikańskiego Mustafy Kemala Atatürka ${ }^{28}$, a także Rosji i jej następcy Związku Radzieckiego, która zaciążyła ludobójstwem, rzeziami, deportacjami, on nie tylko współczuje Ormianom, ale się z nimi i ich dramatycznym losem utożsamia. Otóż Zapiski z podróży wieńczy swobodny przekład legendy armeńskiej, utrwalonej w kronice Faustusa Bizantyjskiego (Biuzanda) ${ }^{29}$, który przedstawił dzieje walk przeciwko Persom. Poeta-tłumacz w stalinowskiej dobie, opowiadając historię króla Arszaka II podstępnie uwięzionego i osadzonego w twierdzy „zapomnienia” Anusz z rozkazu władcy Persów - Szapura, zdaje się w pełni identyfikować ze zniewolonym Ormianinem, któremu okrutny Asyryjczyk „zabrał powietrze” i „trzyma jego serce”.

Otwierający akapit pierwszego z „czysto armeńskich” podrozdziałów umiejętnie anonsuje perspektywę Mandelsztamowskich zapisków z podróży:

На острове Севане, который отличается двумя достойнейшими архитектурными памятниками VII века, а также землянками недавно

w: М. Дэвид-Фокс (red.), Американская русистика: Вехи историографии последних лет. Советский период: антология, Издательство „Самарский университет", Самара 2001, s. 329-374.

${ }^{27}$ О. Мандельштам, Сочинения в четырех томах..., t. 3, s. 184.

28 „Надо сказать, что антиарменизм и политика геноцида были теми политическими векторами, которые практически не менялись ни при каких-сколь угодно резких политических сдвигах в Турции". П. Полян, Причерноморье как амфитеатр геноцида и депортаций, „Неприкосновенный запас” 2012, nr 1, http://magazines.russ.ru/nz/2012/1/ pp8.html (9.04.2016).

${ }^{29}$ История Армении Фавстоса Бузанда, przeł. i kom. М.А. Геворян, [b.w.], Ереван 1953, http://www.vehi.net/istoriya/armenia/buzand/ (12.04.2016). 
вымерших отшельников, густо заросшими крапивой и чертополохом и не более страшными, чем запущенные дачные погреба, я прожил месяц, наслаждаясь стоянием озерной воды на высоте четырех тысяч футов и приучая себя к созерцанию двух-трех десятков гробниц, разбросанных на манер цветника посреди омоложенных ремонтом монастырских общежитий ${ }^{30}$.

Rozpoczynając od obrazu wyspy na jeziorze Sewan, która z przywoływanymi w toku tekstu wyspą Świętej Heleny, kolonizowaną w XVII stuleciu przez Holendrów i Anglików, upadek której zdeterminowała budowa Kanału Sueskiego, czy Maderą, miejscem ucieczki prześladowanych Maurów i Żydów, odkrytą przez Portugalczyków, skolonizowaną przez Hiszpanię, gdzie w roku pracy poety nad utworem (1931) doszło do krwawej rebelii, stłumionej przez Lizbonę, choć nie wprost, ale jednak wiedzie ku paralelom $\mathrm{z}$ kolonizowaną przez wieki Armenią, otoczoną niczym wyspa przez zagrażające, zdecydowanie wrogie jej dominia. I tu także zasygnalizował trzy zasadnicze problemy, i na nich skoncentrował swą narrację: przywracanie i przypominanie o wielkiej i trudnej, nierzadko bolesnej historii tej chrześcijańskiej krainy („два достойнейшие архитектурные памятники VII века"31, „два-три десятка гробниц”); piękno, wieczność i majestatyczność miejscowej przyrody; obraz Armenii radzieckiej („землянки недавно вымерших вшивых отшельников”, „запущенные дачные погреба”, „омоложенные ремонтом монастырские общежития"). Jednak dla potrzeb artykułu skoncentruję się na tych składowych utworu, które w sposób istotny przejawiają postkolonialną świadomość narratora. Warto przede wszystkim zwrócić uwagę na podniesioną już kwestię postawy podróżnika wobec odwiedzanego kraju i jego mieszkańców, której fundament stanowi poczucie kulturowej wspólnoty. Nazywając Armenię „młodszą siostrą ziemi judejskiej”32, Man-

\footnotetext{
${ }^{30}$ О. Мандельштам, Сочинения в четырех томах..., t. 3, s. 179.

31 „Имеются в виду храмы св. Карапета и св. Аракелоца, построенные в 874 г." - О. Мандельштам, Сочинения в двух томах..., t. 2, s. 424.

32 „Был у меня покровитель - нарком Мравьян-Муравьян - муравьиный нарком из страны армянской - этой младшей сестры земли иудейской”. О. Мандельштам, Четвертая проза..., s. 202.
} 
delsztam miał na uwadze proces tworzenia się zrębów antycznej kultury śródziemnomorskiej. Postkolonialny charakter postrzegania przez poetę kultury armeńskiej, który niekiedy trzeba „wydobywać” zza jego metafor czy porównań, stanie się w pełni zrozumiały, gdy przywołam następujący komentarz Edwarda Saida:

Choć wedle Bernala ${ }^{33}$ wiadomo, że korzenie cywilizacji greckiej sięgają Egiptu, kultury ludów semickich [podkr. - I.K.-P.] i różnych innych południowych i wschodnich społeczeństw, została ona w XIX wieku redefiniowana jako „aryjska”, a jej semickie i afrykańskie korzenie albo celowo usunięto, albo ukryto przed wzrokiem laika. Ponieważ greccy pisarze otwarcie przyznawali się do hybrydowości źródeł swojej kultury, europejscy filolodzy nabrali ideologicznego nawyku pozostawiania niewygodnych ustępów bez komentarza, w interesie zachowania attyckiej czystości ${ }^{34}$.

Z powyższego wynika, że na kilka dziesięcioleci przed sformułowaniem „orientalizmu” przez lewicowych intelektualistów, którzy zaangażowali się w krytyczne odczytanie kolonialnego dyskursu imperiów Europy i Ameryki, Mandelsztam dostrzegał jego negatywne „ukracanie” kultury, dopasowywanie jej obrazu do realizacji celów politycznych czy ideologicznych.

Autor interpretowanych zapisków otwarcie stwierdza, że zanurzenie się w środowisku Ormian pozwala mu uwolnić się od strachu, jaki wyzwala w nim współczesna chwila, ponieważ biegu życia tych ludzi i ich wyjątkowo prężnej działalności nie determinuje czas odliczany przez dworcowe czy instytucjonalne zegary, a utrwalana wiekami tradycja: „Мне хотелось поскорее вернуться туда, где черепа людей одинаково прекрасны и в гробу, и в труде" 35 .

Pracujący z materią słowa poeta, pragnąc podkreślić swą bliskość i szacunek wobec tych, do których przybył, niejednokrotnie wyraża zachwyt, jaki wywołuje w nim uroda języka Ormian. Jego cechę naczelną upatruje w zdolności do trwania, w jego niezniszczalności.

${ }^{33}$ Said odsyła czytelnika do dość dyskusyjnej, u swych podstaw afrocentrycznej książki Martina Bernala The Black Athena (1987).

${ }^{34}$ E. Said, Kultura $i$ imperializm, przeł. M. Wyrwas-Wiśniewska, Wydawnictwo Uniwersytetu Jagiellońskiego, Kraków 2009, s. 14.

${ }^{35}$ О. Мандельштам, Сочинения в четьрех томах..., t. 3, s. 187. 
Jest on, konstatuje, jak wyciosane $\mathrm{z}$ kamienia buty, które nigdy się nie znoszą. Choć trudny fonetycznie, oczarowuje. Ale czym, pyta i po chwili odpowiada:

Я испытал радость произносить звуки, запрещенные для русских уст, тайные, отверженные и, может, даже - на какой-то глубине постыдные.

Был пресный кипяток в жестяном чайнике, и вдруг в него бросили щепоточку чудного черного чая.

Так было у меня с армянским языком ${ }^{36}$.

Mandelsztam, wyczulony na piękno jako nieprzemijającą wartość, ceni tych, którzy je tworzyli i uwiecznili w sakralnej architekturze. Ten lud, starszy od Rzymian, pisze ${ }^{37}$, w najzwyklejszej cerkiewce, w tej nędznej ciemnicy, którą zwiedzał we wsi Asztarak, potrafił umieścić kopułę, oddając tym samym cześć zasługującej na pieśni pochwalne przestrzeni wschodu, zachodu, południa i pótnocy zjednoczonej w całość. Poeta zestawia kunszt bezimiennych budowniczych, który przedstawia sobą ta uboga piwnica, jedna z wielu „posłusznych” armeńskich świątyń, z wydawałoby się niepowtarzalnym symbolem powszechnego uwielbienia i władzy rzymską bazyliką św. Piotra i Pawła.

$\mathrm{O}$ pełnym zjednoczeniu podróżującego poety $\mathrm{z}$ Ormianami świadczy jego stwierdzenie, że „wypracował” w sobie szósty „araracki” zmysł, zmysł przyciągania przez górę ${ }^{38}$. Mieszkańcom sowieckiej Armenii, przypomnę, wskutek decyzji bolszewików pozwalano swą świętą górę oglądać jedynie zza kordonu granicy wrogiej od stuleci Turcji, więc służyć jej i czcić ją mogły jedynie

\footnotetext{
${ }^{36}$ Tamże, s. 206. Podczas pobytu w pierwszym otwartym w Armenii pracowniczym domu wypoczynkowym na wyspie Sewan Mandelsztam uczył się ormiańskiego, który przyswajał przy pomocy osobistej nauczycielki ówczesnej pensjonariuszki i studentki Anaidy Chudawierdian, a także studiował staroormiański - grabar. Zob. П. Нерлер, „Путешествие в Армению” u путешествие...

${ }^{37}$ О. Мандельштам, Сочинения в четырех томах..., t. 3, s. 207.

${ }^{38}$ Tamże, s. 206.
} 
wolne obłoki. Ów nowy zmysł, pisze poeta, będzie mu już towarzyszyć zawsze i wszędzie. Postkolonialność w myśleniu i odczuwaniu Armenii przez Mandelsztama znakomicie wychwycił i zinterpretował, choć tak oczywiście tego nie nazwał, poeta i tłumacz Gieorgij Kubotjan. W swym wnikliwym namyśle nad wierszem, otwierającym poetycki cykl „Armenia”, zwraca uwagę na drugą jego strofę:

Окрашена охрою хриплой,

Ты вся далеко за горой,

А здесь лишь картинка налипла

Из чайного блюдца с водой.

Wers drugi, pisze, nigdy nie doczekał się filologicznego komentarza. A kiedy pytał, jak rozumieją go znawcy i miłośnicy twórczości autora Kamienia, w odpowiedzi albo wzruszano ramionami, albo powiadano: napisane zostało w Tbilisi, to i Armenia - hen, za górą. Ale, stwierdza Kubotjan, w całym cyklu poeta odwołuje się tylko do jednej góry - Araratu:

Нет, здесь иное. Преимущественная часть территории нашей страны - за Араратом, за границей... Велика ли эта часть? Если нынешняя Республика Армении занимает чуть менее 30 тысяч квадратных километров, то в 1920 году, по окончании мировой войны, державы-победительницы отвели ей в оставшемся на бумаге Севрском договоре территорию впятеро больше. Земли же, на которых Армения в самом начале IV века приняла крещение и где армяне жили вплоть до геноцида, - 300 тысяч квадратных километров. [...] Вот почему и Мандельштам написал „ты вся”з".

Tak więc kolonizacja trwa i o takim poczuciu utraty zdaje się mówić „szósty zmysł” poety.

Postkolonialna podmiotowość Mandelsztama najpełniejszy wyraz, jak się wydaje, znalazła w podrozdziale opowiadającym o spotkaniu z Aszotem Howhannisjanem. Doszło do niego jeszcze przed podróżą do Armenii, kiedy poeta, chcący się do niej intelektualnie przygotować, udał się do Instytutu Narodów

${ }^{39}$ Г. Куботьян, От слова до слова. Комментарий к изиклу О. Мандельштама „Армения”, „Вопросы литературы” 2005, nr 5, s. 151-152. 
Wschodu ${ }^{40}$. Już w połowie lat 20 . ubiegłego wieku zostały ostatecznie uformowane zasady, na których oparto działalność tej naukowo-badawczej jednostki. W toku ideowych polemik i praktycznych sporów, w zapalczywej dyskusji na argumenty typu: „Нам, конечно, не нужен санскрит, не нужны древнееврейские, финикийские и арамейские языки" ${ }^{41}$, coraz silniejsza stawała się opcja wzywająca do takiego rozwoju, który zabezpieczałby wymagania partii komunistycznej i działań jej organów - handlowych, dyplomatycznych czy milicyjnych.

Już opis miejskiego pejzażu, jaki otacza tę instytucję (Nabrzeże Biersieniewskie; budynek Instytutu położony obok „Domu Władzy” - ogromnego kompleksu mieszkalnego, przypominającego piramidę, który na początku lat 30. zasiedlili wraz z rodzinami członkowie Centralnego Komitetu Wykonawczego czy Rady Komisarzy Ludowych; przewoźnik na rzece Moskwie, pobierający za przeprawę przepełnioną łodzią opłatę w wysokości trzech kopiejek; ciężkie, przesycone mącznym pyłem powietrze), i jej samej (znudzony, niezainteresowany wizytą Mandelsztama młody asystent, wypowiadający kilka ogólnikowych i pustych fraz; niekompetentna pracownica - „русская бабочка-капустница в библиотеке кактусов" ${ }^{42}$ ), wywołuje mroczne i przygnębiające wrażenie. Nie rozwiewa go pojawienie się ówczesnego zastępcy dyrektora Instytutu - Aszota Howhannisjana. Poeta po Czechowowsku kreśli jego portret: despotyczne maniery, duma i pewność siebie, podniesiona wysoko „Prometeuszowa” głowa, która zdaje się unosić niezależnie od reszty ciała. I tu, zupełnie nieoczekiwanie, jak gdyby w sukurs narratorowi przychodzi język ormiański. Słowo „głowa” w tym ję-

\footnotetext{
${ }^{40}$ Poprawna i pełna nazwa: Московский институт востоковедения имени Н.Н. Нариманова. Powstał na bazie Instytutu założonego w roku 1810 przez ormiańskich braci - Iwana i Jekima Łazariewych. Jego celem, w myśl Iwana Łazariewa, było powołanie do życia i subsydiowanie instytucji dydaktycznej „в пользу нации своей”. А.В. Торкунов (red.), Главы из истории московского востоковедения. Лазаревский институт - Московский институт востоковедения - МГИМО, Издательство „Аспект Пресс”, Москва 2014, s. 30 .

41 Tamże, s. 229.

${ }^{42}$ О. Мандельштам, Сочинения в четырех томах..., t. 3, s. 184.
} 
zyku, pisze Mandelsztam, ma ten sam korzeń, jaki w rosyjskim ma wyraz „głuchota”. Ten króciutki podrozdział wieńczy bezpośredni zwrot do czytelnika, w którym wyrażone zostało przekonanie, że ten z pewnością nic zrozumie, a rolą autora nie jest udzielanie mu lekcji.

Co oczywiste, Mandelsztamowska kontestacja sowieckiej kolonizacji nie mogła być sformułowana bezpośrednio, ale przy uwzględnieniu niezbędnego kontekstu historycznego brzmi dość dobitnie. Jeśli za autorem Orientalizmu przyjmiemy, że wiedza o Bliskim Wschodzie, którą wytwarzano i upowszechniano w Europie, „[...] była ideologicznym uzupełnieniem kolonialnej władzy"43, to rzeczony Instytut jest także jednym z jej instrumentów. Ale, co ciekawe, sam Howhannisjan uosabia aż dwa jej wymiary. Był nie tylko dyrektorem metropolitalnej instytucji, lecz także członkiem Komitetu Centralnego Wszechzwiązkowej Komunistycznej Partii (bolszewików) Armenii. I tu Mandelsztam wydaje się powracać do historii skolonizowania tak krótko niepodległej republiki przez Sowietów, której kreatorem był Lenin i jego ormiańscy poplecznicy. To na mocy ich decyzji wojska bolszewickie jeszcze przed podpisaniem pokoju w Brześciu wyszły z terenów Tureckiej Armenii. Nie bacząc na informację wyrażoną przez I Wszechrosyjski Zjazd Żołnierzy-Ormian (3 grudnia 1917 roku), że obnażenie frontu kaukaskiego przez oddziały Armii Czerwonej z pewnością wywoła kolejne rzezie mieszkańców armeńskich ziem. A kiedy w 1918 roku republika się ukonstytuowała, jej los został przypieczętowany. W tajnej instrukcji KC WKP(b), podpisanej między innymi przez Aszota Howhannisjana czytamy:

1. Нынешняя Турция - уже не прежняя султанская Турция и не преследует в отношении Армении агрессивных целей.

2. Кемалистская Турция - союзница Советской России и борется за свое освобождение против империалистических держав - Англии, Франции, Греции.

3. Победа республиканской Армении над Турцией будет означать усиление империализма на Ближнем Востоке и поставит под угрозу победу Революции в Закавказье, и наоборот - поражение республиканской Армении ускорит советизацию всего Закавказья, а также Востока.

${ }^{43}$ A. Loomba, Kolonializm..., s. 60. 
4. Задачей армянских большевиков-коммунистов должно быть ускорение поражения республиканской Армении, что ускорит советизацию Армении ${ }^{44}$.

W przytoczonym kontekście portret Howhannisjana i jego tło, które utrwalił w swych zapiskach Mandelsztam, stają się w pełni czytelne i zrozumiałe.

Parafrazując Saida, piszącego o Richardzie Burtonie, można stwierdzić, że Podróż do Armenii autorstwa żydowsko-chrześcijańskiego poety doby stalinizmu poświadcza taką historię postkolonialnej świadomości, która, wynikając z umotywowanego intelektualnie i emocjonalnie szacunku, przedziera się przez meandry odległej kultury, która nie tylko ją interioryzuje, ale w pełni się z nią utożsamia $^{45}$. A taką otwartą perspektywę umożliwia, w przekonaniu Mandelsztama, kontemplująca świat, wolna od ideowych oków sztuka. A więc nie miał racji Szkłowski, ponieważ autor za obrazami, które zdają się odsyłać do odległej tradycji, do bibliotek i pokrytych kurzem wykopalisk z czasów Urartu, z troską pochyla się nad ówczesnym dniem i przyszłością sowietyzowanej Armenii. Mylił się i inny funkcyjny krytyk tamtych czasów, niejaki S. Rozental ${ }^{46}$, który w sierpniowym numerze gazety „Prawda” z roku 1933 pisał:

${ }^{44}$ Инструкция ЦК, КП(б) Армении от 20 сентября 1920 года. Cyt. za: Г.П. Хомизури, Социальные потрясения в судьбах народов (на примере Армении), Интеллект, Москва 1997, http//26.itmc.ru>social.doc (2.04.2016).

45 „Как авантюрист путешественник Бертон ощущал самого себя живущим одной жизнью с тем народом, на землях которого он находился. [...] Он не только безукоризненно говорил по арабски, ему также удалось проникнуть в самое сердце ислама и, выдавая себя за доктора-мусульманина из Индии, совершить паломничество в Мекку. Однако, на мой взгляд, самой поразительной чертой Бертона является то, что он постоянно сознавал, до какой степени человеческая жизнь в обществе управляется правилами и кодами. [...] Ни одному человеку, который не знал бы арабский язык и ислам так, как их знал Бертон, не удалось бы зайти по пути паломничества в Мекку и Медину так далеко. Так что перед нами история человека, проникшего в чужую культуру за счет успешного освоения ее системы информации и поведения”. Э.В. Саид, Ориентализм. Западные концепции Востока, przeł. А.В. Говорунов, „Русский Міръ”, Санкт-Петербург 2006, s. 307-309, http://e-libra.ru/read/350390-orientalizm.html (11.04.2016).

${ }^{46}$ Niestety, nie udało mi się ustalić imienia. 
Какой бедный мир, мир маркера и гурмана! [...] От образов Мандельштама пахнет старым, прелым, великодержавным шовинистом, который, расточая похвалы Армении, хвалит ее экзотику, ее рабское прошлое, ибо о настоящем не написал ни строки Мандельштам. Так „путешествовать” можно, сидя в комнате и окружив себя гравюрами, старинными книгами и раритетами армянской старины... Так говорили, писали и „путешествовали” до революции поэты „Вены”, кабака на Морской улице, поэты затхлых салонов, герои литературных „пятниц” и „сред”. Старый петербургский поэт-акмеист О. Мандельштам прошел мимо бурно цветущей и радостно строящей социализм Армении ${ }^{47}$.

Zachwiana ze zdwojoną siłą tożsamość poety, z uwagi na jego żydowskość i wymuszoną pozycję outsidera w sowieckim środowisku literackim początku lat $30 .^{48}$, pragnęła dowieść swego twórczego, kulturowego i etycznego zakorzenienia i prawomocności. W poszukiwaniu odwagi („Я бы взял с собой мужество в желтой соломенной корзине с целым ворохом пахнущего щелоком белья, а моя шуба висела бы на золотом гвозде. И я бы вышел на вокзале в Эривани с зимней шубой в одной руке и со стариковской палкой - моим еврейским посохом ${ }^{49}-$ в другой" ${ }^{50}$.) udał się do odległej terytorialnie, prowincjonalnej, ale bliskiej sercu, bo wpisanej w tak drogi mu krąg kultury śródziemnomorskiej, Armenii ${ }^{51}$. Jej tragiczne doświadczenie kolonializmu,

${ }^{47}$ О. Мандельштам, Сочинения в двух помах..., t. 2, s. 420. Tę wypowiedź określił poeta, jak wspomina Nadieżda Mandelsztam, mianem bulwarowej („желтопрессная”).

48 Zob. А. Жолковский, „Я пью за военные астры...”: поэтический автопортрет Мандельштама, w: tegoż, Избранные статьи о русской поэзии, РГГУ, Москва 2005, s. 60-82, http://www-bcf.usc.edu/ alik/rus/ess/ bib31.htm (16.04.2016).

49 „Давно замечена близость исторических судеб евреев и армян, и распространяться на этот счет излишне. Разве что стоит напомнить: Иудея, как и Западная (Турецкая) Армения, лишилась исконного населения в результате единовременной волевой акции”. Г. Куботьян, Бегство в Армению и другие этюды о Мандельштаме, „Вопросы литературы” 2012, nr 3, http://magazines.russ.ru/voplit/2012/3/kk2.html (16.04.2016).

50 Tamże.

${ }^{51}$ Michaił Gasparow konstatuje, że Armenia swą kulturową pamięcią stanowiła dla Mandelsztama straż przednią helleńskiego chrześcijaństwa. М. Гаспаров, 
brutalnej dominacji kolejnych powstających imperiów - perskiego, rzymskiego, osmańskiego, rosyjskiego i radzieckiego wreszcie, $\mathrm{z}$ jednoczesnym walecznym trwaniem przy własnej tożsamości narodowej, utrwalonej w języku, religii czy literaturze, wyzwoliło w Mandelsztamie poczucie własnej wartości jako artysty, umożliwiło duchowo-twórcze odrodzenie, którego wyrazem był, między innymi, cykl poetycki „Armenia”.

$* * *$

Ilja Kukulin, należący do nielicznego grona badaczy rosyjskich rozpoznających praktyki kolonialne w kulturze i literaturze rosyjskiej ${ }^{52}$, uważa, że w latach 70 . XX wieku w ZSRR rozpoczął się pierwszy etap rozwoju „pisma wewnętrznej dekolonizacji” ${ }^{53}$, którego źródeł upatruje w środowisku nieoficjalnej kultury, a reprezentują je teksty, między innymi, Aleksandra Sołżenicyna, Siemiona Lipkina czy Fazila Iskandera. Konkludując swe interpretacje, dotyczące ich wypowiedzi publicystycznych czy też utworów stricte literackich, pisze:

О русской поэзии: Анализы. Интерпретаиии. Характеристики, Азбука, Санкт-Петербург 2001, http://sobolev.franklang.ru/index.php/nachalo-xxveka/94-m-gasparov-o-mandelshtame-iii (21.04.2016).

52 А. Эткинд, Внутренняя колонизаиия. Имперский опыт России, przeł. В. Марков, Новое литературное обозрение, Москва 2013; A. Etkind, D. Uffelmann, I. Kukulin (red.), Там, внутри. Практики внутренней колонизации в культурной истории России, Новое литературное обозрение, Москва 2012; С.Н. Абашин, Советский кишлак: Между колониализмом и модернизацией, Новое литературное обозрение, Москва 2015; М. Могильнер, Ното ітрегіi: история физической антропологии в России (конеи, XIX - начало XX в.), Новое литературное обозрение, Москва 2008; М.В. Тлостанова, Деколониальные гендерные эпистемологии, Маска, Москва 2009. Trudno nie odnotować, że najczęściej są to badacze związani z zachodnimi ośrodkami naukowymi. W Rosji studiom postkolonialnym patronuje wydawnictwo Nowoje Litieraturnoje Obozrienije i międzynarodowe czasopismo „Ab Imperio”.

${ }^{53}$ Formuła „wewnętrznej kolonizacji” to przykład wykorzystania przez naukowców rosyjskich wypracowanego na Zachodzie aparatu badawczego do stworzenia własnej metodologii. 
Характерные особенности этого периода - описание современного мира как поликультурного, поиск места в этом мире для коллективного целого („русских”, „тавларов”, „чегемцев/абхазов”) и представление о том, что естественной рамкой для поликультурного общества является государство ${ }^{54}$.

Zasadne wydaje się uzupełnienie spisu przywołanych przez Kukulina literatów o nazwisko Jurija Karabczijewskiego, choć nie jestem przekonana o pełnej przydatności jego koncepcji ${ }^{55}$.

Ponieważ twórczość Karabczijewskiego i w Rosji, i w Polsce ${ }^{56}$ jest mało znana, przytoczę garść informacji, mających znaczenie dla podjętego tematu. Ów z wykształcenia inżynier-elektronik zadebiutował w pierwszej połowie lat 60., kiedy to ukazały się dwie publikacje prezentujące jego wiersze. Po wydarzeniach roku 1968 zdecydował, że Związek Radziecki to nie miejsce dla jego utworów i odtąd w kraju

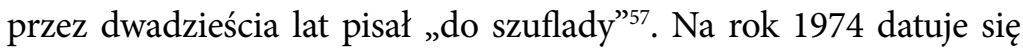
natomiast początek jego aktywnej współpracy z tamizdatem, wówczas w czasopiśmie „Wiestnik RChD” ukazał się jego esej Ulica Mandelsztama - jedna z pierwszych interpretacji zapoznanego przez lata poetyckiego geniusza i, co podkreśla Kubatjan, najbardziej w owym czasie znacząca ${ }^{58}$. Ważnym wydarzeniem w podziemnej działalności

54 И. Кукулин, „Внутренняя колонизация”: формирование постколониального сознания в русской литературе 1970-2000 годов, „Политическая концептология" 2013, nr 2, s. 179.

55 „Развитие этих постклониальных мотивов определялось двумя типами отношения к колонизируемым территориям, сформировавшимся в послевоенном СССР: аккультурацией и освоением”. Tamże, s. 149.

${ }^{56}$ Hasło dedykowane pisarzowi znajduje się jedynie w Przewodniku po literaturze rosyjskiej i jej okolicach (1917-1996) Tadeusza Klimowicza, próżno go szukać w słowniku Wolfganga Kasacka czy w słowniku pisarzy rosyjskich XX wieku pod redakcją P.A. Nikołajewa.

57 Zob. Интервью, данное Юрием Карабчиевским Сергею Шаповалову в апреле 1992 года, http://old.magazines.russ.ru/novyi_mi/arhiv/karab/interv. html (9.04.2016).

${ }^{58}$ Г. Кубатьян, Безвестный поэт. Заметки о Юрии Карабчиевском, „Дружба Народов” 2010, nr 9, http://magazines.russ.ru/druzhba/2010/9/ku15.html (12.04.2016). 
literackiej poety był jego udział w „MetrOpolu”,59, ale nigdy nie był on dysydentem w pełnym znaczeniu tego słowa, nie interesowała go aktywność polityczna, nie uprawiał pisarstwa zorientowanego „antyradziecko", a to, paradoksalnie, zauważa Leonid Batkin, powodowało, że był bardziej nieoficjalny od innych ${ }^{60}$.

Problematyka Tęsknoty za Armenia Jurija Karabczijewskiego (Тоска по Армении, 1975) została skoncentrowana na trzech, wzajemnie się przecinających, płaszczyznach tematycznych: realistycznej opowieści ${ }^{61}$ o służbowej podróży radzieckiego inżyniera-elektronika do Erywania, którą zapełniają obrazy sowieckiej codzienności Ormian; próby odczytania Mandelsztamowskiej wizji Armenii i jej jako utęsknionego właśnie domu, „odnalezienia” przez podróżującego i ukrywającego swe własne pasje literackie ${ }^{62}$ tegoż inżyniera; i wreszcie, jak słusznie zauważa Simon Markisz, poszukiwanie własnej tożsamości przez rosyjskiego Żyda, zasymi-

${ }^{59} \mathrm{~W}$ kontekście peregrynacji naukowych Kukulina można przypomnieć, że współautorem „MetrOpolu” był Siemion Lipkin. Zob. I. Kowalska-Paszt, Słowo w poszukiwaniu wolności. Poezja w „Metropolu”, w: M. Alieksiejenko (red.), Славянские языки в свете культуры, ООО „А Темп”, Москва-ЩецинГрайфсвальд 2006, s. 295-311.

60 Л. Баткин, Тоска по России, „Дружба Народов” 1999, nr 6, http://magazines. russ.ru/druzhba/1999/6/batkin.html (23.03.2016).

${ }^{61}$ Tamże. Batkin, pisząc o poetyce prozatorskich tekstów Karabczijewskiego, stwierdza, że ich autor to „realista czystej wody”, że za pierwszym wrażeniem tradycyjności jego narracji, za jej staromodną schludnością pozbawioną jakiejkolwiek gry, kryje się odczuwalna współczesność jego stylu.

62 „Две маленькие журнальные публикации (в 1961-м и 1965-м) оказались для него [Juria Karabczijewskiego - I.K.-P] на долгие десятилетия первыми и последними. Сочинять он стихи сочинял, однако печатать уже не помышлял. Даже на Западе, где регулярно появлялась его проза. И только на волне писательской своей востребованности - в пору перестройки все, что было им когда-либо создано, прежнее и новое, безотказно принимали ведущие журналы, — на нежданной-негаданной этой волне он опубликовал дюжины полторы стихотворений в 'Дне поэзии' и 'Юности', 'Новом мире' и 'Огоньке', 'Литературной газете' и 'Согласии'. Книгу же поначалу собирать не хотел, однако в конце концов и собрал, и придирчиво составил, и даже подписал в печать. В печать Юрий Карабчиевский подписал ее 25 июля 1992-го. Через пять дней он покончил с собой. Ему не исполнилось и пятидесяти четырех". Г. Кубатьян, Безвестный поэт... 
lowanego bezgranicznie, aż do pełnej narodowo-kulturowej anihilacji ${ }^{63}$. Jednak tytuł utworu najbardziej więc koresponduje z ostatnimi dwoma wśród wskazanych tematami.

Odczytaniu utworu w perspektywie postkolonialnej wydaje się sprzyjać komentarz do niego, jaki w osiem lat po jego napisaniu sporządził autor ${ }^{64}$. Przyczyny jego powstania wiążą się z realną postacią sportretowaną w Tęsknocie za Armenią, prozaikiem Grantem Matewosjanem, który, co podnosił „uważny i mądry” czytelnik, wywołał nadmierny $i$ bezzasadny zachwyt autobiograficznego narratora-Jury ${ }^{65}$. W bezpośrednim zwrocie pisarza do będącego $\mathrm{z}$ nim na ty czytelnika pojawia się stwierdzenie, że w odróżnieniu od Ormianina on mieszka w samym centrum imperium i tworzy w dominującym („господствующий”) w nim języku. Przywołane zdanie, po pierwsze, świadczy, że Karabczijewski zdawał sobie sprawę $\mathrm{z}$ imperialnego dyskursu polityki i kultury ZSRR, a, po drugie, wcale nie przeciwstawia obu twórców, lecz wręcz przeciwnie, wskazuje na poczucie wspólnoty pisarskich losów. Jednocześnie uświadamia ono, że postkolonialna tożsamość Karabczijewskiego jest hybrydowa, ponieważ jej skonfliktowane składowe to wzniesiona na żydowskim pochodzeniu i dysydenckich podwalinach poety/pisarza tożsamość subalterna oraz hegemona, wynikająca $z$ jego identyfikacji z kulturą i językiem rosyjskim.

Źródła owej rozchwianej tożsamości narratora stanowią przedmiot jego monologu wewnętrznego, który pojawia się tekście pod wpływem rozmowy z Sjuzanną, pracownicą jednego z erywańskich instytutów badawczych. Interlokutorzy nie zgadzają się w swych ocenach Mandelsztamowskiej Podróży do Armenii - Sjuzanna w końcowym momencie sporu zadaje pytanie, czy Jura jest Rosjaninem i czy zna swój język:

${ }^{63}$ Ш. Маркиш, Бабель и другие, Мосты культуры - Гешарим, Иерусалим 1997, s. 209.

${ }^{64}$ Ю. Карабчиевский, Послесловие к повести „Тоска по Армении”, „Новый мир” 1993, nr 10, http://magazines.russ.ru/novyi_mi/1993/10/karab.html (2.04.2016).

${ }^{65}$ Taką opinię sformułował między innymi przywoływany już Leonid Batkin. 
Боже, как просто спросить и как сложно ответить! Не знаю? Или: мой это русский? И с какой интонацией: легкомысленной, грустной, гордой? То мгновение, что я промалчиваю перед ответом, я слышу, заполняется сухими щелчками. [...] Я русский, я самый настоящий русский. (Имелось в виду: такой же, как все.) И если бы не проклятая отметка в паспорте (имелось: не длинный нос, не форма глаз и ушей, не походка, не детские впечатления, не образ мышления, наконец), то я бы никогда и не вспоминал. А язык - да Господи! - ну конечно, этот и только он. Этот вездесущий, разлитый в любом пространстве, заполняющий каждый предмет, составляющий суть любого явления, обожаемый до боли, до сладострастия, знакомый до тонкостей, до извращений, и все же вечно непостижимый, мучительно ускользающий в каждый момент - какой же еще, как не этот! Какой же еще мне родной, когда я никакого другого и знать не знаю?.. И вот тут-то, может быть, червоточинка. „Никакого другого не знаю”, - говорю я обычно, и точно ли? да, пожалуй, так: с гордостью. Уж во всяком случае, без сожаления. Потому что это лишний раз подтверждает. Конечно, еврей, я не отказываюсь, но по сути, граждане, какой я еврей? Я ведь и языка-то такого еврейского... ${ }^{6}$

Żydzi rosyjscy, mieszkańcy jednej z największych kolonii w imperium rosyjskim, której terytorium wyznaczała granica osiedlenia (черта оседлости) - prawny instrument imperialnej dominacji ${ }^{67}$, z biegiem wydarzeń historycznych i społecznych — opóźnionej w stosunku do Europy haskali, pogromów przełomu wieku, wpływu teorii i praktyki marksistowskiej, holocaustu i późniejszej sowietyzacji albo tracili swą żydowską tożsamość całkowicie, albo, często dramatycznie, zmagali się ze swą rozchwianą żydowsko-rosyjską samoidentyfikacją. Karbczijewskij w Tęsknocie za Armeniq kreśli portret Sirgieja Asojana, swego „najlepszego znaleziska” w Armenii. Wychowany w Rosji radzieckiej przez już zruszczonych rodziców dwudziestoletni chłopak poczuł przyciąganie swej rodzinnej armeńskiej ziemi, przyjechał do jej stolicy, nauczył się języka od podstaw, przeniknął jej historią, wrósł w krąg jej problemów i ludzi, i stał się na powrót Ormianinem („Такой молодец”). Udana próba wyzwolenia się od narzucanej i odzyskania utraconej narodowej tożsamości przez Asojana, jego literackie zainteresowa-

\footnotetext{
${ }^{66}$ Ю. Карабчиевский, Тоска по Армении, http://old.magazines.russ.ru/novyi_ $\mathrm{mi} /$ arhiv/karab/toska.html (14.04.2016).

${ }^{67}$ А. Эткинд, Внутренняя колонизация..., s. 135.
} 
nia i jego opublikowany w czasopiśmie „Litieraturnaja Armienija” artykuł o Mandelsztamie, i jeszcze wspólny im obu zachwyt prozą Matewosjana sprawią, że Jura lgnie ku niemu jako wyjątkowo bliskiemu, choć nowo poznanemu, przyjacielowi.

W Tęsknocie za Armenia można odnaleźć niejeden przejaw bezpośredniej postkolonialnej narracji: utrwalone w dniu powszednim, w zinterioryzowanych wartościach, w zunifikowanej architekturze Erywania, w nawykach i języku Ormian wpływy kolonialnych działań rusyfikacyjnych, a przede wszystkim sowietyzujących. Warto natomiast przyjrzeć się bliżej napięciom intelektualnym i emocjonalnym, jakie powstają pomiędzy uznanym pisarzem Matewosjanem a Karabczijewskim, ale nie w przestrzeni utworu, a poza nim, co znalazło swój wyraz w autorskim komentarzu. Podczas pierwszego spotkania z prozaikiem w jego mieszkaniu narrator interpretowanego tekstu dostrzega po raz pierwszy od przyjazdu do Armenii maszynę do pisania z ormiańską czcionką i wysłuchuje rozważań tego, jak uważa, stuprocentowego Ormianina o kraju, jego ludziach i problemach. A sprowadzają się one do konstatacji, że mieszkańcy dzisiejszej Armenii, niestety, tracą swą narodową identyfikację, że i miasta, i wsie naznaczone zostały utratą, a jej przyczyną było odżegnanie się od własnej religii:

Для армян, как ни для одной нации в мире, оказался губительным отказ от религии. Христианство для армян было всем, а не просто многим. Ведь Армения - первая страна в мире, где христианство стало государственной религией. Армяне как будто только ее и ждали, были к ней абсолютно готовы. Церковь стала государством, школой, наукой, литературой, культурой. Божий храм оставался для армянина духовным и организующим центром даже тогда, когда он утратил это значение для всех других христианских народов. Даже в национальной жизни поляков церковь не играла такой исключительной роли. Но поляки с честью пронесли свое католичество через все катаклизмы, а армяне оказались духовно слабее, не выдержали, отказались - и остались ни с чем. И комукому, а им это с рук не сойдет. Я не знаю, не знаю, сохранимся ли мы теперь как народ, только чудо нас может спасти... ${ }^{68}$

Jednym słowem wymuszona ateizacja wiedzie ku zgubie, $\mathrm{ku}$ zniszczeniu podwalin duchowych tego niewielkiego i wiekami ko-

${ }^{68}$ Ю. Карабчиевский, Тоска по Армении... 
lonizowanego narodu. A mówiąc to Matewosjan ma oczy przepełnione łzami. W komentarzu autor Tessknoty za Armenia przypomina, że Grant to i praobraz, i obraz literacki. Jednak nie mogło nie wywrzeć wrażenia na Karabczijewskim stwierdzenie „prawdziwego Ormianina", jakie zamieścił w przedmowie do kolejnego wydania jego książki Twój ród (Твой pod, 1986): „[...] я же постараюсь быть летописцем $[\ldots]$ высоких дел моего народа, сегодняшней возродившейся и уверенной в будущем Советской Армении"69.

Tęsknota za metaforycznym Domem ${ }^{70}$ wiodła rosyjskiego pisarza-inżyniera śladami Mandelsztama do Armenii, chciał wykrzyczeć i światu, i sobie „Jestem Ormianinem”, miał nadzieję, że ludzie mogą się porozumiewać i tworzyć wspólnotę ponad podziałami politycznymi, ekonomicznymi, kulturowymi czy rasowymi. Matewosjan jej nie ma i dlatego w roku 2000, pytany przez swą rodaczkę Anait Bajandur (tłumaczka, nota bene wspomina o niej w swoim utworze Karabczijewskij) o przyszłość ich kraju, powie:

В административных границах России, в пределах ее политической мысли складывалась и историческая наша память, и видение будущего. [...] Прецеденты самостоятельности, культурного самоуправления были, - когда все окрест было под Персией, или же, скажем, в 1801 году, когда Кавказ перешел к России и стал фактически культурно-национальной автономией, объявленной или необъявленной - неважно ${ }^{71}$.

Matewosjan jawi się więc nie tyle jako człowiek i pisarz bliski artystycznemu obrazowi prozy autora Tęsknoty za Armenia, ile jako uosobienie wprowadzonego do studiów postkolonialnych przez Homiego Bhabhę pojęcia mimikry ${ }^{72}$.

\footnotetext{
${ }^{69}$ Г. Матевосян, Моему читателю, http://modernlib.ru/books/grant_matevosyan/moemu_chitatelyu/read_1/ (22.04.2016).

${ }^{70}$ Tęsknota za domem - tytuł prozatorskiego zbioru Karabczijewskiego, który ukazał się w roku 1991.

${ }^{71}$ Интеграция - путь разума. Анаит Баяндур беседует с Грантом Матевосяном, „Дружба Народов” 2000, nr 12, http://magazines.russ.ru/ druzhba/2000/12/inter.html (13.04.2016).

${ }^{72} \mathrm{H}$. Bhabha, Mimikra i ludzie. O dwuznaczności dyskursu kolonialnego, przeł.

T. Dobrogoszcz, „Literatura na Świecie” 2008, nr 1/2, s. 184-195.
} 
Odmowa legitymizacji, choć specyficznego, ale kolonialnego w swej istocie dyskursu władzy sowieckiej i podporządkowanej jej kultury, w przypadku Osipa Mandelsztama oparta była na jego wiedzy i szacunku dla tradycji kulturowej Armenii, u Karabczijewskiego zaś związana była $z$ umotywowanymi etycznie emocjami, jakie wyzwolili w nim współcześni mu Ormianie i ich literatura.

Изабела Ковальска-Пашт

ПОСТКОЛОНИАЛЬНЫЕ ЗАПИСКИ О ПУТЕШЕСТВИИ В «КОЛОНИЮ». ОСИП МАНДЕЛЬШТАМ ПУТЕШЕСТВИЕ В АРМЕНИЮ, ЮРИЙ КАРАБЧИЕВСКИЙ ТОСКА ПО АРМЕНИИ

Резюме

Прозаические записки Мандельштама и Карабчиевского, выбранные для критического прочтения, вписаны в армянский текст русской литературы (Александр Пушкин, Валерий Брюсов, Сергей Городецкий, Андрей Белый, Анна Ахматова, Василий Гроссман, Андрей Битов). Принятая в статье методология позволяет проанализировать ту составляющую их произведений, которой является посколониальное сознание путешествующих литераторов, а его истоком могла послужить позиция аутсайдера в советской культуре. Автобиографические повествователи Мандельштам и Карабчиевский - кажется, полностью отождествляют себя с неоднократно трагическим опытом многовековой колониальной доминации, который стал уделом армян. Причем главную роль в постколониальной оптике автора Путешествия в Армению играют его особо глубокие знания об истории и культуре этой страны, а в Тоске по Армении - этически мотивированные эмоции путешественника.

Izabela Kowalska-Paszt

POSTCOLONIAL NOTES FROM THE TRIP TO THE “COLONY”. OSIP MANDELSTAM PUTESHESTVIYE V ARMENIYU, JURII KARABTCHIYEVSKY TOSKA PO ARMENII

Summary

Prosaic notes by Mandelstam and Karabtchiyevski selected for critical reading contribute to the Armenian text in the Russian literature (Alexander Pushkin, Valery Bryusov, Sergey Gorodetsky, Andrei Bely, Anna Akhmatova, Vasily Grossman, Andrei Bitov). A methodology adopted in the article enables analyzing the 
postcolonial awareness of travelling authors expressed in the two works, and its origin one should look for in the position of an outsiders in the Soviet culture. The autobiographic narrators - Mandelstam and Karabtchiyevsky - seem to be fully associated with a frequently tragic experience of a centuries long colonial domination suffered by Armenians. While the attitude of the author of the Journey to Armenia is supported by exceptionally broad knowledge about history and culture of the country, the main role in Longing for Armenia is played by well-motivated ethical emotions of the traveler. 